\title{
РОЛЬ ЕВРАЗИЙСКОГО БАНКА РАЗВИТИЯ В ФОРМИРОВАНИИ ЕДИНОГО ТРАНСПОРТНОГО ПРОСТРАНСТВА ЕАЭС "
}

\author{
(c) 2021 Алексеев Петр Викторович \\ кандидат экономических наук, \\ ведущий научный сотрудник Института мировой экономики и международных финансов \\ Финансовый университет при Правительстве Российской Федерации, Россия, Москва \\ E-mail: palekseev@fa.ru
}

Одним из направлений углубления интеграционного сотрудничества в рамках ЕАЭС является формирование Единого транспортного пространства (ЕТП) ЕАЭС, которое позволит более эффективно реализовать транспортный и транзитный потенциал Союза. Важная роль в этом процессе отводится Евразийскому банку развития (ЕАБР). В статье выявлены проблемы, сдерживающие эффективную реализацию транспортного и транзитного потенциала ЕАЭС, а также предложены меры по повышению роли ЕАБР в формировании ЕТП ЕАЭС.

Ключевые слова: Евразийский экономический союз, единое транспортное пространство, Евразийский банк развития, транспортная инфраструктура, цифровые транспортные коридоры.

В 2000-х годах проблемам формирования ЕТП на евразийском пространстве уделяется большое внимание со стороны государств и экспертов. Теоретические и практические вопросы, связанные с формированием ЕТП, рассмотрены в работах Л.Б.Вардомского, Е.Ю.Винокурова, С.Ю.Глазьева, М.С. Комова, О.Н.Ларина, С.Г.Лузянина, Ю.В.Морозова, М.О.Тураевой, Б.А.Хейфеца, В.А.Цветкова и многих других. Тем не менее, в целом данная проблематика остается недостаточно изученной.

Формирование ЕТП ЕАЭС предусмотрено Договором о ЕАЭС от 29 мая 2014 г. В соответствии со ст. 86 Договора, в Союзе осуществляется скоординированная (согласованная) транспортная политика, направленная на обеспечение экономической интеграции, последовательное и поэтапное формирование единого транспортного пространства (ЕТП) на принципах конкуренции, открытости, безопасности, надежности, доступности и экологичности. Формирование ЕТП осуществляется посредством поэтапного создания к 2025 г. общего рынка транспортных услуг (ОРТУ). Вопросы дальнейшей интеграции в сфере естественных монополий и сфере транспорта закреплены в разделах XIX «Естественные монополии» и XXI «Транспорт» Договора о ЕАЭС [1].

В развитие положений Договора о ЕАЭС 26 декабря 2016 г. Высший Евразийский экономический совет Решением № 19 утвердил Основ- ные направления и этапы реализации скоординированной (согласованной) транспортной политики государств-членов ЕАЭС, целями которых являются дальнейшее формирование и развитие единого транспортного пространства и общего рынка транспортных услуг Союза.

Данные цели достигаются путем решения следующих задач:

- принятие согласованных мер по обеспечению общих преимуществ в сфере транспорта и реализация наилучших международных практик, в том числе содействие более полной реализации географических преимуществ Союза при осуществлении транзитных транспортноэкономических связей между Европой и Азией, изучение, анализ и согласованное внедрение передового зарубежного опыта;

- интеграция транспортных систем государств-членов в мировую транспортную систему;

- эффективное использование Союзом своего транзитного потенциала;

- повышение качества транспортных услуг.

Реализация Основных направлений осуществляется с учетом следующих приоритетов:

- создание и развитие евразийских транспортных коридоров;

- координация развития транспортной инфраструктуры;

- развитие науки и инноваций в сфере

\footnotetext{
* Статья подготовлена по результатам исследований, выполненных за счет бюджетных средств по государственному заданию Финуниверситету.
} 
транспорта;

- расширение научно-технического сотрудничества, обмена информацией, передовым опытом («ноу-хау») с целью развития транспортных технологий [2].

Правовое регулирование в рамках ЕАЭС направлено на проведение скоординированной (согласованной) транспортной политики, последовательное и поэтапное формирование ЕТП на принципах конкуренции, открытости, безопасности, надежности, доступности и экологичности. ЕТП как важный структурный компонент единого экономического пространства ЕАЭС формируется посредством поэтапного создания к 2025 г. общего рынка транспортных услуг. По мнению профессора Л.Б.Вардомского, этот рынок позволит удешевить и ускорить взаимные перевозки, обеспечить гарантированный и равный доступ к услугам национального транспорта всех стран-участниц при перевозках внутри Союза и между государствами Союза и третьими странами. Одна из главных задач ЕТП и ОРТУ превратить транзит из барьера в фактор, содействующий развитию стран-участниц. По мере продвижения в направлении создания ОРТУ, в ЕАЭС будет действовать единый транзитный тариф для отдельных видов транспорта. Это касается не только перевозок между странами ЕАЭС, но и транзита, обеспечивающего перевозки между ними и третьими странами, а также между третьими странами [3].
По мнению профессора О.Н.Ларина, «интеграция транспортных систем ЕАЭС с учётом различий правового регулирования, технологических особенностей отдельных видов транспорта и состояния транспортной инфраструктуры должна содействовать экономическому росту союзных государств, снижению их транспортной изолированности, расширению внутрисоюзных и международных экономических связей и увеличению объёмов транзитных перевозок» [4].

ЕАБР в своей инвестиционной деятельности большое внимание уделяет финансированию проектов в области транспортной инфраструктуры, являющейся важнейшим структурным компонентом ЕТП ЕАЭС, формируемого в соответствии с Договором о ЕАЭС*. В инвестиционном портфеле ЕАБР доля проектов в транспортной сфере составила на 1 ноября 2019 года 18,3\% [5]. По состоянию на 25 января 2021 г. ЕАБР финансирует 6 проектов в данной сфере (таблица 1).

В настоящее время развитие транспорта в ЕАЭС характеризуется положительной динамикой: общий объем транспортировки грузов всеми видами транспорта стран ЕАЭС увеличился с 5786,5 млрд. тонно-километров в 2015 г. до 6410,1 млрд. тонно-километров в 2019 г., или на 11\%. При этом общий объем перевозок пассажиров всеми видами транспорта увеличился с 43890,0 млн. пассажиров в 2015 г. до 44607,5 млн. пассажиров в 2019 г., т.е. на 1,6\% [6].

В целом, на наш взгляд, транспортный и

* Формирование ЕТП предусмотрено ст. 86 Договора о ЕАЭС. Вопросы интеграции в сфере транспорта закреплены в разделе XXI «Транспорт» Договора о ЕАЭС.

Таблица 1. Инвестиционные проекты ЕАБР в сфере транспортной инфраструктуры на 25 января 2021 г.

\begin{tabular}{|c|l|c|}
\hline № п/п & \multicolumn{1}{|c|}{ Наименование проекта } & \multicolumn{1}{|c|}{ Сумма } \\
\hline 1. & $\begin{array}{l}\text { Финансирование строительства магистрального газопровода «Сарыарка» } \\
\text { (Республика Казахстан) за счет приобретения Банком облигаций АО «АстанаГаз } \\
\text { КМГ» }\end{array}$ & 102 млрд. тенге \\
\hline 2. & $\begin{array}{l}\text { Финансирование строительства Государственной транспортной лизинговой } \\
\text { компанией (Россия) сухогрузного судна проекта RSD59 и 10 нефтеналивных } \\
\text { барж проекта «БЕЛМАКС» для последующей передачи в лизинг }\end{array}$ & 50,47 млн. долл. \\
\hline 3. & $\begin{array}{l}\text { Финансирование строительства нефтеналивных танкеров типа RST54 (3 ед.) и } \\
\text { RSТ27 (2 ед.) на российской судоверфи ОАО «Окская судоверфь» }\end{array}$ & 50,21 млн. долл. \\
\hline 4. & $\begin{array}{l}\text { Финансирование строительства на платной основе ООО «Автодорожная строи- } \\
\text { тельная корпорация» автомобильной дороги ЦКАД-3 в соответствии с Феде- } \\
\text { ральным законом от 21.07.2005 г. № 115-Ф3 «О концессионных соглашениях» }\end{array}$ & 10 млрд. рублей \\
\hline 5. & $\begin{array}{l}\text { Строительство вагоноремонтного комплекса и промывочно-пропарочной } \\
\text { станции ТОО «ЦВС-ЕСКЕНЕ» в Атырауской области Республики Казахстан }\end{array}$ & 56 млн. долл. \\
\hline 6. & $\begin{array}{l}\text { Внедрение и сопровождение автоматизированной системы RЕМS Сепtral АО } \\
\text { «Транстелеком» Р Республике Казахстан в рамках внедрения стратегического } \\
\text { проекта «Автоматизированная система управления «Энергодиспетчерская } \\
\text { тяги» }\end{array}$ & 7,5 млрд. тенге \\
\hline
\end{tabular}

Источник: URL: http://eabr.org/projects/eabr. Дата обращения: 26.01.2021 г. 
транзитный потенциал ЕАЭС используется недостаточно эффективно, что обусловлено наличием ряда проблем, в том числе:

- относительно невысоким уровнем развития транспортной инфраструктуры, включая её высокий физический и моральный износ (например, в Армении по этой причине не функционирует порядка 40\% построенных железных дорог [7]);

- различиями в национальных законодательствах государств-членов ЕАЭС, регламентирующих вопросы функционирования отдельных отраслей промышленности и видов транспорта [7];

- сложностями, связанными с различиями в понятийном аппарате, используемом в национальном законодательстве государств-членов ЕАЭС, регламентирующем вопросы функционирования отдельных видов транспорта [7];

- фрагментированностью единой таможенной территории ЕАЭС вследствие присоединения Республики Казахстан к ВТО с отличными от единого таможенного тарифа (ЕTT) тарифными обязательствами по 20\% позиций (например, средний тариф по сельскохозяйственной продукции для Казахстана составляет 10,2\%, в то время как для прочих стран ЕАЭС - 17\%; по ряду товаров, в том числе чувствительных для российского рынка, уровень тарифной защиты Казахстана на 60\% ниже ЕTT [8];

- сохранением препятствий на внутреннем рынке ЕАЭС (по данным Евразийской экономической комиссии, на 25 января 2021 г. всего на региональном рынке сохранялись 59 препятствий [9]);

- негативными последствиями пандемии коронавируса COVID-19, начавшейся в 2019 г.

В соответствии со Стратегией ЕАБР на период с 2018 по 2022 год, важнейшим приоритетом проектной деятельности Банка является развитие транспортной инфраструктуры, состояние которой во многом влияет на перспективы интеграции на евразийском пространстве.

Согласно Стратегии, основным направлением работы Банка по развитию транспортной инфраструктуры является финансирование проектов, способствующих интеграции и формированию единого транспортного пространства ЕАЭС. Это в полной мере соответствует положениям Основных направлений и этапов реализации скоординированной (согласованной) транспортной политики государств-членов Евразийского экономического союза, утвержденных Решением Высшего Евразийского экономического совета от 26 декабря 2016 г. № 19, а также достижению целей национальных отраслевых стратегий развития.

В настоящее время наиболее перспективным направлением развития транспортной инфраструктуры является формирование международных цифровых транспортных коридоров (ЦТК)*. Эта цель определена в качестве одной из приоритетных в Решении Высшего Евразийского экономического совета от 11 октября 2017 г. № 12 «Об основных направлениях реализации цифровой повестки Евразийского экономического союза до 2025 года».

По нашему мнению, создание ЦТК в рамках ЕАЭС имеет значительный потенциал для развития евразийской интеграции, при условии разработки и принятия единой стратегии и реализации на ее основе совместных проектов. В противном случае, при проведении автономной цифровой политики в процессе формирования в ЕАЭС общего рынка транспортных услуг, будут возникать дополнительные барьеры. В этой связи необходимо обоснование целесообразности разработки единой стратегии создания евразийских цифровых транспортных коридоров, которые бы позволили эффективно реализовать транспортный и транзитный потенциал ЕТП ЕАЭС.

Относительно высокая доля инвестиций в транспортную отрасль в структуре инвестиционного портфеля ЕАБР (около 20\% на 1 сентября 2020 г.) способствует развитию международной кооперации государств-членов ЕАЭС в данной сфере интеграционного сотрудничества. Однако его потенциал используется недостаточно эффективно вследствие относительно небольшого

\footnotetext{
* Цифровой транспортный коридор (ЦТК), согласно определению, данному экспертами,- это гетерогенная информационно-сервисная цифровая платформа, интегрирующая информационные ресурсы участников международного транспортного коридора и формирующая вокруг него доверительное информационное пространство с целью цифровизации и повышения эффективности сквозных бизнес-процессов в трансконтинентальных цепочках поставок, оптимизации использования инфраструктуры и транспортных средств международного транспортного коридора, а также предоставления комплекса информационно-справочных, аналитических, управленческих и платежных услуг (реферат НИР «Концептуальный проект создания экосистемы цифровых транспортных коридоров Евразийского экономического союза». C. 20. URL: http://www. eurasiancommission.org. Дата обращения: 25.01.2021).
} 
размера оплаченного уставного капитала ЕАБР, ограниченного доступа Банка к инструментам привлечения и размещения ликвидности в национальных валютах стран-членов [10], а также более высоких процентных ставок по кредитам ЕАБР по сравнению с коммерческими банками и национальными институтами развития стран ЕАЭС [11].

В целом для повышения роли ЕАБР в развитии международной кооперации и интеграции государств-членов ЕАЭС в области транспорта и формировании ЕТП Союза целесообразно акцентировать внимание на следующих направлениях:

1. В целях повышения эффективности участия ЕАБР в развитии кооперации в сфере транспортного сообщения между странами ЕАЭС следует обосновать и разработать единую стратегию создания евразийских цифровых транспортных коридоров.

2. В целях оптимизации распределения инвестиционных ресурсов ЕАБР для финансирования кооперационных проектов в отраслях экономики стран ЕАЭС, включая создание единых транспортных коридоров в регионе, дополнить перечень стратегических контрольных показателей деятельности ЕАБР показателем «Объем ресурсов, привлекаемых путем выпуска долговых инструментов на развитие отдельных отраслей экономики стран ЕАЭС, включая транспортную инфраструктуру».

3. В интересах ускорения формирования единого транспортного пространства в рамках ЕАЭС необходимо разработать согласованные подходы к унификации законодательства государств-членов ЕАЭС, регламентирующего вопросы функционирования отдельных видов транспорта.

4. Актуальной задачей является формирование единого понятийного аппарата, применяемого в национальном законодательстве государств-членов ЕАЭС для регламентации вопросов функционирования отдельных видов транспорта.

5. В интересах повышения роли ЕАБР в формировании цифровых транспортных коридоров ЕАЭС дополнить Приложение к Рекомендации Совета Евразийской экономической комиссии от 3 марта 2017 г. № 2 «О перечне взаимовыгодных направлений кооперационного сотрудничества государств-членов Евразийского экономического союза с учетом целесообразности финансирования соответствующих проектов Евразийским банком развития» пунктом 9 «Формирование цифровых транспортных коридоров Евразийского экономического союза».

Вышеприведенные меры окажут содействие повышению роли ЕАБР в формировании ЕТП ЕАЭС, а также успешному развитию евразийской экономической интеграции.

\section{Библиографический список}

1. Договор о Евразийском экономическом союзе от 29 мая 2014 г. (с изменениями и дополнениями) // СПС «Гарант». Дата обращения: 25.01.2021.

2. Основные направления и этапы реализации скоординированной (согласованной) транспортной политики государств-членов ЕАЭС (утверждены Решением Высшего Евразийского экономического совета от 26 декабря 2016 г. № 19) // СПС «Гарант». Дата обращения: 25.01.2021.

3. Вардомский Л.Б. Евразийская интеграция и Большое евразийское партнерство // Россия и новые государства Евразии. 2019. № 3.

4. Ларин О.Н. Перспективы интеграции транспортных систем Евразийского экономического союза // Проблемы национальной стратегии. 2017. № 3.

5. Доклад о результатах ежегодного мониторинга кооперационного взаимодействия и реализации кооперационных проектов. М.: ЕЭК, 2019. URL: http://www.eurasiancommission.org. Дата обращения: 25.01.2021.

6. Статистический ежегодник Евразийского экономического союза.- М.: ЕЭК, 2020. URL: http://www. eurasiancommission.org. Дата обращения: 25.01.2021.

7. Комов М. С. Сотрудничество в транспортной сфере как фактор развития региональной экономической интеграции в Евразийском экономическом союзе // Московский экономический журнал. 2019. № 13.

8. Глазьев С. Ю. Рывок в будущее. Россия в новых технологических и мирохозяйственных укладах.- М.: Книжный мир, 2018.

9. URL: https://barriers.eaeunion.org/ru-ru/Pages/obstacles.aspx. Дата обращения: 26.01.2021.

10. Стратегия Евразийского банка развития на период с 2018 по 2022 год. URL: https://eabr.org/upload/data/ strategy_2018_2022.pdf. Дата обращения: 25.01.2021.

11. Тюлебеков Т.Б. Евразийский банк развития как один из инструментов региональной интеграции на постсоветском пространстве // Актуальные научные исследования в современном мире. 2019. № 11. 